\title{
Effect of Mulvap 100\% EC. (Dichlorvos) Spray Schedules on the Control of Insect Pests and Yield of Cowpea (Vigna Unguiculata L. Walp) in
Enugu, Southeastern Nigeria
}

\author{
Awere, S.U. ${ }^{1}$; Omeje, T.E. ${ }^{2}$
}

\author{
${ }^{1}$ Department of Agronomy and Ecological Management, Enugu State University of Science and Technology, P.M. B 01660 \\ Enugu Nigeria. \\ ${ }^{2}$ Department of Agricultural Technology, Enugu State Polytechnic Iwollo, Enugu Sate Nigeria.
}

\begin{abstract}
A field experiment to evaluate the effect of mulvap100\%Ec. (Dichlorvos) spray schedules on the control of insect pests, and yield of cowpea (Vigna unguiculata L. Walp) was carried out during the 2016 cropping season at the Faculty of Agriculture and Natural Resources Management Teaching and Research Farm of Enugu State University of Science and Technology Enugu, Southeastern Nigeria, using a randomized complete block design (RCBD) with four treatments replicated five times. There was a significant $(P=0.05)$ effect of mulvap100\%Ec. Spray schedules on all the parameters assessed. Mulvap100\%Ec. Sprayed every 7 days performed significantly $(P=0.05)$ better than any other insecticide spray schedule in the control of cowpea insect pests, in addition to producing significantly higher pod yield. This was followed by the insecticide sprayed every 14 days, every 21 days and no insecticide sprayed respectively. Plants sprayed with mulvap $100 \%$ Ec. every 7 days recorded mean number of 0.00 aphids per plant, $2.69 \%$ leaf damage by leaf beetles, mean number of 0.64 flower thrips, 0.11 maruca larvae per plant, $0.35 \%$ dimpled and shriveled seeds and pod yield of 0.26 tonha $^{-1}$ , followed by plants sprayed with the insecticide every 14 days that recorded mean number of 13.38 aphids per plant, 3.89\% leaf damage by leaf beetles, mean number of 1.89 flower thrips per flower, mean number of 0.57 maruca larvae per flower, $1.89 \%$ dimpled and shriveled seeds, and pod yield of 0.13 tonha $^{-1}$ and lastly plants sprayed with no insecticide that recorded mean number of 23.39 aphids per plant, $5.49 \%$ leaf damage by leaf beetles, mean number of 4.94 flower thrips per flower, mean number of 1.41 maruca_larvae per flower, $3.81 \%$ dimpled and shriveled seeds, and pod yield of 0.11 tonha $^{-1}$ .Keywords-Cowpea (Vigna unguiculata), insecticide, spray schedules, cowpea insect pests.
\end{abstract}

\section{INTRODUCTION}

Cowpea (Vigna unguiculata L. Walp) is one of the most widely used legumes in the tropical world. The grain is used extensively for human nutrition. It is a major vegetable source of protein for human consumption especially in Africa (Ileke et al. 2013). Cowpea is a staple component of the diet in several developing countries and a major source of protein to combat malnutrition in young children in Lieu of expensive animal protein. Cowpea seed contains about $25 \%$ protein, making it extremely valuable in areas where many people cannot afford proteinous foods such as meat and fish (Lephale et al. 2001). It has been regarded as poor man's meat (Ileke $e t$ al. 2012). It is an extremely important protein source to Vegetarians and people who cannot afford animal protein (Adeyemi et al. 2012). Cowpea seeds are also a rich source of minerals and vitamins (Hall et al. 2003). The green and dry haulm are fed to livestock particularly in dry seasons when animal feed is scarce (Ababe et al. 2005) and also as source of income when sold to farmers who use them as livestock feed (Dugje et al. 2009). Cowpea is a warm weather crop that is well adapted to drier regions of the tropic like Nigeria where other food legumes do not thrive well. (Abate et al. 2011). Nigeria is its Largest producer and consumer, accounting for about 45 percent of its world's production (Lowenberg-Deboer and Ibro 2008), Ndong et al. 2012) while Africa accounts for $75 \%$.

However, the production and the storage of this important crop have faced so many constraints. Okelede and Ariyo (2000) stated that the production of this crop in Nigeria is low and has not matched the demand of the consumers. They also noted that the shortfall in cowpea production is traceable to problem of poor yield resulting from multifarious insect pests and diseases affecting the crop at different stages of development as well as continuous use of low yielding varieties. 
Traditional farmers apply little or no insecticide on cowpea and consequently obtain low yield. Variations among environments for cowpea grain yield where greater when no insecticide was applied than where it was not used (Blade et al. 1992). Field insect pests can even cause colossal loss in yield of cowpea ( Amatobi et al. 2005). They also noted that without the control of insect pests of cowpea, reasonable grain yield cannot be obtained. Several control measures are available but chemicals are more effective, giving several fold increase in grain yield. However, most small scale farmers do not adequately control insect pests and diseases because of the high cost of chemicals and labour (Opole et al. 2005). Many entomologists have made efforts to identify the safe and effective chemicals and also optimum number of spray for controlling the most important pests of cowpea, particularly those affecting flowers and pods (Adejumo, 2005, Opole et al. 2005). Therefore the general objective of this research work was to evaluate the effect of mulvap100\%Ec. on the control of insect pests and yield of cowpea in Enugu, southeastern Nigeria.

\section{MATERIALS AND METHODS}

A field experiment to evaluate the effect of mulvap $100 \%$ Ec. spray schedules on the control of insect pests, and yield of cowpea was carried out during the 2016 cropping season at the Faculty of Agriculture and Natural Resources Management Teaching and Research Farm of Enugu State University of Science and Technology Enugu, Southeastern Nigeria.

\section{Experimental Design.}

The experiment was carried out using a randomized complete block design (RCBD) with four treatments replicated five times. The experimental area measured 14 $\times 11 \mathrm{~m}\left(154 \mathrm{~m}^{2}\right)$. The experimental units (plots) measured $2 \mathrm{~m} \times 2 \mathrm{~m}\left(4 \mathrm{~m}^{2}\right)$ and were separated by $1 \mathrm{~m}$ pathway. Three seeds were sown per hole at a spacing of $50 \mathrm{~cm} \times 50 \mathrm{~cm}$ and later thinned down to two plants per hole at 7 days after germination.

Treatment. 1.5 liter/ha of mulvap100\%Ec. at four spraying schedules viz; 0 liter/ha sprayed, 1.5 liter/ha sprayed every 7 days till harvest, 1.5 liters/ha sprayed every 14 days till harvest, 1.5 liters /ha sprayed every 21 days till harvest.

\section{Data Collection.}

Data were collected on;

- The number of cowpea aphids (Aphis craccivora) per plant, a total of 10 plants were sampled per experimental units. A plastic bowel was half filled with water and aphids found on each plant were dislodged into the bowel. The water that contained the aphids was filtered with a sieve of $0.15 \mathrm{~mm}$ or 150 micro mesh size and the aphids counted.
- Percentage leaf damage by leaf beetles (Ootheca mutabilis and Luperodes lineata).

- The number of flower thrips per flower. This was done by removal of 10 flowers every 2 days for 3 consecutive times starting from 7 days after flower initiation and counting the number of flower thrips in them.

- Number of maruca_larvae per flower. The same 10 flowers used for flower thrips count were used for this purpose.

- Percentage seed damage by pod sucking bugs were determined by calculating the percentage wrinkled and dimpled seeds at harvest.

\section{Statistical Analysis.}

The data collected were analyzed using the genstat release (2012) and analysis of variance outlined by Obi 2001.

\section{RESULTS}

Effect of Mulvap100\% Ec.(Dichlorvos) spray schedules on the number of aphids per plants, percentage leaf damage by leaf beetles and number of flower thrips per flower.

The result of the experiment showed a significant $(\mathrm{P}=0.05)$ insecticide spray schedules on the mean number of aphids per plant, percentage leaf damage by leaf beetles and mean number of flower thrips per flower. Plants sprayed with the insecticide every 7 days has no aphids per plant indicating a hundred percent (100\%) aphid control which also differed significantly from the rest of the spray schedules. Plants sprayed every 14 days had a mean number of 13.38 aphids per plant which differed significantly $(\mathrm{P}=0.05)$ from plants sprayed every 21 days and those sprayed with no insecticide that recorded mean number of 20.08 and 23.39 aphids per plant respectively. However, plants sprayed with insecticide every 21 days recorded mean number of aphids that did not significantly differ from those sprayed with no insecticide (Table 1).

On the mean percentage leaf damage by the leaf beetles, there was a significant $(\mathrm{P}=0.05)$ insecticide spray schedules effect with plants sprayed every 7 days recording the least mean percentage of 2.69 damaged leaves by leaf beetles, followed by plants sprayed every 14 days having a mean number of $3.89 \%$ damaged leaves and lastly plants sprayed with no insecticide with a mean of $5.49 \%$ damaged leaves by leaf beetles, which did not significantly differ from plants sprayed every 21 days that recorded a mean of $4.08 \%$ damaged leaves (Table 1). There was also a significant $(\mathrm{P}=0.05)$ insecticide spray schedules effect on the mean number of flower thrips per flower. Plants sprayed with insecticide every 7 days recorded the least mean number of 0.64 flower thrips per flower that differed significantly $(\mathrm{P}=0.05)$ from the rest of the spray schedule, followed by plants sprayed every 14 
days that had a mean of 1.87 flower thrips per flower and

of 4.49 flower thrips per flower (Table 1).

lastly, plants sprayed with no insecticide having a mean

Table.1: Effect of Mulvap100\%Ec.(Dichlorvos) spray schedules on the mean number of aphids per plants, percentage leaf damage by leaf beetles and mean number of flower thrips per flower.

\begin{tabular}{cccc}
\hline Spray schedules (days) & $\begin{array}{c}\text { mean number of } \\
\text { Aphids per plants }\end{array}$ & $\begin{array}{c}\text { mean percentage leaf } \\
\text { damage by leaf beetles }\end{array}$ & $\begin{array}{c}\text { mean number of } \\
\text { flower thrips per flower }\end{array}$ \\
\hline
\end{tabular}

\begin{tabular}{cccc}
0 & 23.39 & 5.49 & 4.94 \\
7 & 0.00 & 2.69 & 0.64 \\
14 & 13.38 & 3.89 & 1.87 \\
21 & 20.08 & 4.08 & 2.67 \\
F-LSD 0.05 & 4.25 & 0.99 & 1.06 \\
\hline
\end{tabular}

\section{Effect of Mulvap100\%Ec.(Dichlorvos) spray schedules} on the number of Maruca larvae per flower, percentage dimpled and shriveled seeds caused by pod sucking bugs and pod yield (tonha ${ }^{-1}$ ).

The result of the experiment showed a significant $(\mathrm{P}=0.05)$ effect on the mean number of Maruca larvae per flower with plants sprayed every 7 days recording the least mean number of 0.11 Maruca larvae per flower, followed by plants sprayed with the insecticide every 14 days having a mean number of 0.57 Maruca larvae per flower and lastly plants sprayed with no insecticide that had a greater mean number of 1.41 Maruca larvae per plant which differed significantly from plants sprayed every 21 days that had a mean number of 0.66. Maruca larvae per plant. Again, there was a significant $(\mathrm{P}=0.05)$ effect of Mulvap100\%Ec. spray schedules on the mean percentage dimpled and shriveled seeds caused by pod sucking bugs with plants sprayed every 7 days recording the least mean percentage of 0.35 dimpled and shriveled seeds, followed by plants sprayed with the insecticide every 14 days that recorded a mean percentage of 1.89 dimpled and shriveled seeds which differed significantly from the rest of the insecticide spray schedules. Furthermore, there was a significant $(\mathrm{P}=0.05)$ effect of mulvap $100 \%$ Ec. spray schedules on pod yield with plants sprayed every 7 days recording the highest mean pod yield of 0.26 tonha $^{-1}$, followed by plants sprayed every 14 days having a mean pod yield of 0.13 tonha $^{-1}$ and lastly plants sprayed with no insecticide recording 0.11 tonha $^{-1}$ that did not differ significantly $(\mathrm{P}=0.05)$ from the rest insecticide spray schedules, except that of every 7 days spray schedule (Table 2).

Table.2: Effect of Mulvap100\%Ec.(Dichlorvos) spray schedules on the number of Maruca larvae per flower, percentage dimpled and shriveled seeds caused by pod sucking bugs, and pod yield(tonha ${ }^{-1}$ ).

\begin{tabular}{cccc}
\hline Spray schedules (days) & $\begin{array}{c}\text { mean numbers of } \\
\text { Maruca larvae/plant }\end{array}$ & $\begin{array}{c}\text { mean number of dimpled } \\
\text { and shriveled seed }(\%)\end{array}$ & $\begin{array}{c}\text { pod yield } \\
\text { (tonha }^{-1} \text { ) }\end{array}$ \\
\hline 0 & 1.14 & 3.81 & 0.11 \\
7 & 0.11 & 0.35 & 0.21 \\
14 & 0.57 & 1.89 & 0.13 \\
21 & 0.66 & 1.96 & 0.12 \\
F-LSD 0.05 & 0.36 & 1.38 & 0.12 \\
\hline
\end{tabular}

\section{DISCUSSION AND RECOMMENDATION}

A hundred percent $(100 \%)$ control of aphids by Mulvap100\%Ec. (Dichlorvos) sprayed every 7 days showed that a regular application of this insecticide to cowpea plants is necessary for a total eradication of this cowpea insect pest. Apart from total eradication of aphids on this important leguminous crop, this insecticide sprayed every 7 days on cowpea plants that recorded lower levels of leaf beetles, flower thrips, Maruca larvae and pod sucking bugs infestation, also emphasized the importance of regular application of this insecticide.

Furthermore, Mulvap100\%Ec.(Dichlorvos) sprayed every 7 days on cowpea plants recording a significant $(\mathrm{P}=0.05)$ higher mean pod yield of 2.26tonha ${ }^{-1}$ also showed the importance of regular application of insecticide to improve pod yield in cowpea. These findings agreed with the following researchers; Alabi et al. (2003) indicated that low yield is not inherent in cowpea but mainly caused by insect pests attack. They also noted that controlling flowering and podding pests resulted in highest grain yield per plot. He however recommended applying insecticide once weekly during flowering and podding stage than applying it once every week through the cowpea growing period. A similar result was reported by (Algali 1992), which suggested that insect pests of flowers and pods were most important in reducing grain 
yield. Karugi et al. (2000) reported that regular application of insecticide generally reduce cowpea insect pests infestation and markedly increase yield. Isubikalu, (2002). Omongo et al. 1998 indicated that in some parts of Nigeria like the North, large scale cowpea producers, sometimes apply insecticides as many as 8-10 times during the growing season to control insect pests. They also suggested that 10 days interval insecticide application (4 times) can be as profitable as 7 days interval application (5 times) in cowpea production. Again, (Emosairue et al. 2004), observed that insecticide at present offer the only effective control of pests and a crop sprayed weekly from the first day after planting (DAP) can out yield an unsprayed crop by eight to nine times $(784 \mathrm{~kg} / \mathrm{ha}$ ), and less frequent application (every two weeks) gave intermediate yield of $452 \mathrm{~kg} / \mathrm{ha}$, if started 21 DAP, $243 \mathrm{~kg} / \mathrm{ha}$ and if started 35 DAP, $187 \mathrm{~kg} / \mathrm{ha}$.

As a result of this experiment, I suggest that cowpea producers in Enugu area, southeastern Nigeria should practice spraying of insecticide to growing cowpea plants weekly starting from one week after germination for the purpose of controlling cowpea insect pests attack and maximizing pod/grain yield. This is so because, this insecticide spraying interval is close enough to meet flowering and podding stages which were observed by some researchers as the critical stages of cowpea growth at which insecticide application significantly $(\mathrm{P}=0.05)$ minimizes pod/grain yield loss due to insect pests (Alabi et al. 2003).

\section{REFERENCES}

[1] Ababe, G., Hatler, B. and Att-Tawah, A. (2005). Nutrient availability as affected by manure application to cowpea (Vigna unguiculata L, Walp) calcarious soil. Journal of Agricultural science 1:26.

[2] Adejumo, T.O., (2005). Crop protection strategies for major disease of Cocoa, Cowpea, Coffee and Cashew nut in Nigeria. Africa Journal of Biotechnology 4(2) 143-150.

[3] Adeyemi,S.A, Lewu,F.B, Adebola, P.O, Bradley, G and Okoh, A.I. (2012). Protein content variation in cowpea genotypes (Vigna unguiculata (L) Walp) grown in the eastern cape province of South Africa as affected by mineralized goat manure. African Journal of Agricultural Research vol. 7(35), 49434947.

[4] Alghali, A.M (1992). On farm evaluation of control strategies for insect pests in cowpea with emphasis on flower thrips (Megalurothrips sjostedti). ). International Journal of Pests Management 49(4), 287-291.

[5] Alibi, 0.A., Odebiyi, J.A., and Jackai, L.E.N.(2003). Field evaluation of cowpea cultivars
(Vigna unguiculata (L) Walp) for resistance to flower bud thrips (Megalurothrips sjostedti). Tropical pests Management, 37:71-74.

[6] Amatobi, A.M, Dike, M.C, Opareke, A.M. (2005). Integrated pests Management of report thrips and maruca on cowpea at Samaru; cropping scheme meeting on legume and oil seed research programme, IAR Ahmadu Bello University, Zaria Nigeria 5:23-24.

[7] Blade, S.E. (1992). Cowpea on traditional cropping system. International Institution of Tropical Agricultural Science (JIRCAS 11TA) P 36.

[8] Dugje, I.Y., Omoigui, L.O., Ekeleme,F., Kamara, A.Y. and Ajeigbe H. (2009). Farmers Guide to cowpea production in West Africa. 11TA Ibadan Nigeria P 20.

[9] Hall,A.E, Cisse,N.,Thiaw,S., Elawad, H.O.A, Ehlers, J.D.,(2003). Development of Cowpea Cultivars and grain plasma by the bean/cowpea CRSP. Field crops Research 82: 103-134.

[10] Ileke, K.D, Odenymi, O.O and Ahamo, M.O. (2013). Varital resistance of some cowpea cultivars to cowpea Bruchid, (Callosobruchus maculates F,) infestation.FUTA Journl of Research in science vol.1, 72-81.

[11]Ileke, K.D, Odeyemi, O.O and Ahamo, M.O. (2012). Insecticide activities of Alstoma Boonelde wild powder against cowpea seed Bruchid. International Journal of Boilogy 4(2)125-131.

[12] Isubikalu， P. (2002). Understanding farmer knowledge of cowpea production and M.Sc. Pests management. A case study of Ugamda P15. eastern Ugamnda. Thesis, Makereke University Uganda P 158.

[13] Karugi, J., Adipala, E., Ogenga-Latigo, M.W., Kyamanywa, S. and Oyobo, N.(200).plant Pests Management in cowpea, part 1. Influence of planting time and density on cowpea field infestation in eastern Uganda. Crop protection 19:231-236.

[14]Lephale,S, Addo-Benediako, A and Ayodele V. (2001) susceptibility of seven cowpea varieties to beetle (Callosoruchus maculatus). Agricultural Science.

[15] Lowenberg-Deboer, J., and Ibro, G. (2008). A study of the cowpea value chain in Kano State, Nigeria from a pro-and Gender prospective. A paper Commissioned by GATE project P16.

[16] Ndong, A., Kebe, K.H., Thiaw, C.H., Diome, T. and Sembene, M. (2012). Genetic distribution of the cowpea (Vigna unguiculata (L) Walp) Bruchid (Callosobruchus) maculatus(F)) population in different agro-ecological areas of West Africa. Journal of Animal Science Adv.(F) 616-630. 
[17] Obi, I.U. (2001). Introduction to factorial experiment for Agricultural, Biological and Social Sciences Research ( $2^{\text {nd }}$ Edition).

[18] Okelede, K.A and Ariyo, O.J., (2000). Effect of strip inter cropping and Insecticide spray on the performance of cowpea (Vigna unguiculata).

[19] Opele, R.A., Mathenga, P.W., Auma, E.O., Van Rheehen, H.A., and Wambugu, P.W.(2005). Strategic practices for improving bean seed production in Western Kenya. Africa crop Science Conference proceedings 7,123-128. 